\title{
PENGARUH PENDAPATAN ASLI DAERAH DAN DANA ALOKASI UMUM TERHADAP BELANJA MODAL PADA KABUPATEN DAN KOTA DI PULAU JAWA TAHUN 2013
}

\author{
Wimpi Priambudi \\ Prodi Akuntansi Universitas Negeri Yogyakarta \\ wimpipriambudi@gmail.com
}

\begin{abstract}
Abstrak: Pengaruh Pendapatan Asli Daerah dan Dana Alokasi Umum Terhadap Belanja Modal Pada Kabupaten Dan Kota Di Pulau Jawa Tahun 2013. Penelitian ini bertujuan untuk mengetahui: (1) Pengaruh Pendapatan Asli Daerah terhadap Belanja Modal pada Kabupaten dan Kota di Pulau Jawa Tahun 2013. (2) Pengaruh Dana Alokasi Umum terhadap Belanja Modal pada Kabupaten dan Kota di Pulau Jawa Tahun 2013. (3) Pengaruh Pendapatan Asli Daerah dan Dana Alokasi Umum secara bersama-sama terhadap Belanja Modal pada Kabupaten dan Kota di Pulau Jawa Tahun 2013. Teknik analisis data menggunakan uji prasyarat analisis data, dan uji hipotesis. Hasil penelitian ini menunjukkan: (1) Pendapatan Asli Daerah berpengaruh positif dan signifikan terhadap Belanja Modal, ditunjukkan dengan angka koefisien korelasi $\left(\mathrm{r}_{1 \mathrm{y}}\right)$ sebesar 0,862; koefisien determinasi $\left(\mathrm{r}^{2}{ }_{1 \mathrm{y}}\right) 0,744$; $\mathrm{t}_{\text {hitung }} 17,539>\mathrm{t}_{\text {tabel }}$ 1,98282. (2) Dana Alokasi Umum berpengaruh positif dan signifikan terhadap Belanja Modal, ditunjukkan dengan angka koefisien korelasi $\left(\mathrm{r}_{2 \mathrm{y}}\right)$ sebesar 0,610; koefisien determinasi $\left(\mathrm{r}^{2}{ }_{2 y}\right) 0,372$; $\mathrm{t}_{\text {hitung }} 7,920>\mathrm{t}_{\text {tabel }}$ 1,98282. (3) Pendapatan Asli Daerah dan Dana Alokasi Umum berpengaruh positif dan signifikan secara bersama-sama terhadap Belanja Modal, ditunjukkan dengan angka koefisien korelasi $\left(\mathrm{R}_{1,2 \mathrm{y}}\right)$ sebesar 0,912 ; koefisien determinasi $\left(\mathrm{R}_{1,2 \mathrm{y}}{ }^{2}\right.$ 0,$832 ; \mathrm{F}_{\text {hitung }} 260,766>\mathrm{F}_{\text {tabel }} 3,08$.
\end{abstract}

Kata kunci: Pendapatan Asli Daerah, Dana Alokasi Umum, Belanja Modal

Abstract: The Impacts of Locally- Generated Revenue and General Allocation Grant Toward Capital Expenditure of Districts and Cities in Island, in 2013. The aims of this research are: (1) to know the impacts of Locally-Generated Revenue towards Capital Expenditure of districts and cities in Java, in 2013. (2) To know the impacts of General Allocation Grant towards Capital Expenditure of districts and cities in Java, in 2013. (3) To know the impacts of both Locally-Generated Revenue and General Allocation Grant altogether towards Capital Expenditure of districts and cities in Java, in 2013. The method of data analysis used were prerequisite data analysis test, and hypothesis test. The results show that: (1) Locally-Generated Revenue has a significant and positive effect in Capital Expenditure, depicted as 0,862 in coefficient correlation number $\left(r_{1 y}\right)$; and 0,744 in coefficient of determination ( $\left.r_{1 y}^{2}\right) ; t_{\text {counted }} 17,539>t_{\text {table }} 1$,98282. (2) ) General Allocation Grant has a significant and positive effect in Capital Expenditure, depicted as 0,610 in coefficient correlation number $\left(r_{2 y}\right)$; 0,372 in coefficient of determination $\left(r^{2}{ }_{2 y}\right) ; t_{\text {counted }} 7,920>t_{\text {table }} 1,98282$. (3) Both Locally-Generated Revenue and General Allocation Grant have significant and positive effect altogether towards Capital Expenditure, as depicted as 0,912 in coefficient correlation number $\left(R_{1,2 y}\right)$; and 0,832 in coefficient of determination $\left(R^{2}{ }_{1,2 y}\right) ; 0,832 ; F_{\text {counted }} 260,766>F_{\text {table }} 3,08$.

Key words: Locally-Generated Revenue, General Allocation Grant, Capital Expenditure. 


\section{PENDAHULUAN}

Daerah yang berada di wilayah Republik Indonesia tidak dapat terlepas dari adanya peran dari pemerintah pusat dan pemerintah daerah dalam hal menjalankan fungsi pemerintahan yang ada pada di setiap daerah. Namun, dengan adanya Undang-Undang Nomor 23 Tahun 2014 Tentang Pemerintahan Daerah, yang berlaku pada setiap daerah di wilayah Republik Indonesia menjadikan pemerintah daerah memiliki pelimpahan kewenangan dengan cakupan luas untuk mengurus rumah tangganya sendiri serta meminimalisir campur tangan pemerintah pusat. Dengan cakupan tersebut, pemerintah daerah dapat mempermudah penjaringan aspirasi masyarakat sehingga diperoleh gambaran yang cukup tentang kebijakan jangka pendek, jangka menengah, dan kebijakan jangka panjang yang berkaitan dengan kebijakan pengelolaan keuangan daerah.

Belanja Modal merupakan pengeluaran anggaran yang digunakan untuk perolehan aset tetap dan aset lainnya yang memberi manfaat lebih dari satu periode akuntansi (PP No. 24 Tahun 2005). Belanja Modal sangat berkaitan dengan perencanaan keuangan jangka panjang, terutama pembiayaan untuk pemeliharaan aset tetap yang dihasilkan dari Belanja Modal tersebut. Dari dalam mengatur segala kas milik daerah untuk dipergunakan dalam public service di daerah.

Peraturan Pemerintah (PP) Nomor 58 Tahun 2005 memberikan penegasan bahwa daerah memiliki kewenangan untuk menentukan alokasi sumber daya ke dalam Belanja Modal dengan menganut asas kepatutan, kebutuhan dan kemampuan daerah. Pemerintah daerah, bekerjasama dengan Dewan Perwakilan Rakyat Daerah sebagai lembaga legislatif terlebih dahulu menentukan Kebijakan Umum APBD (KUA) dan Prioritas \& Plafon Anggaran Sementara (PPAS) sebagai petunjuk (guidance) dalam pengalokasian sumber daya dalam APBD. KUA dan PPAS merupakan konkretisasi dari hasil konsep Multi-Term Expenditure Framework (MTEF) menyatakan bahwa kebijakan Belanja Modal harus memperhatikan kemanfaatan (usefulness) dan kemampuan keuangan pemerintah daerah (budget capability) dalam pengelolaan aset tersebut dalam jangka panjang (Allen dan Tommasi, 2001).

Pemerintah daerah mengalokasikan dana dalam bentuk anggaran Belanja Modal dalam APBD untuk menambah aset tetap dan aset lainnya yang memberi manfaat lebih dari satu periode akuntansi. Anggaran Belanja Modal ini didasarkan pada kebutuhan daerah akan sarana dan 


\section{JURNAL NOMINAL / VOLUME VI NOMOR 1 / TAHUN 2017}

prasarana, baik untuk kelancaran pelaksanaan tugas pemerintah maupun untuk fasilitas publik. Pada dasarnya, pemerintah tidak mempunyai uang yang dimiliki sendiri, sebab seluruhnya adalah milik publik (Mardiasmo, 2002:67), oleh karena itu dalam upaya meningkatkan kualitas pelayanan publik, pemerintah daerah seharusnya mengubah komposisi belanjanya. Selama ini belanja daerah lebih banyak digunakan untuk belanja rutin yang relatif kurang produktif. Juli Panglima Sarangih (2003) menyatakan bahwa pemanfaatan belanja hendaknya dialokasikan untuk hal-hal produktif.

Pada Undang-undang Nomor 32 Tahun 2004 disebutkan bahwa salah satu sumber pendapatan daerah adalah Pendapatan Asli Daerah (PAD), yang terdiri dari hasil pajak daerah, hasil retribusi daerah, hasil pengelolaan kekayaan daerah yang dipisahkan, dan lain-lain PAD yang sah. Menurut Mardiasmo (2002) saat ini masih banyak masalah yang dihadapi pemerintah daerah terkait dengan upaya meningkatkan penerimaan daerah keterbatasan sarana dan prasarana yang tidak mendukung untuk investasi menimbulkan pertanyaan bagaimana sebenarnya PAD terhadap Belanja Modal, apakah karena PAD yang rendah atau alokasi yang kurang tepat.

Setiap daerah berbekal kemampuan keuangan yang beragam dalam mendanai kegiatan-kegiatannya, hal ini menimbulkan ketimpangan fiskal antara satu daerah dengan daerah lainnya, oleh karena itu untuk mengatasi ketimpangan fiskal pemerintah pusat mengalokasikan dana yang bersumber kepada APBN untuk mendanai kebutuhan daerah dalam pelaksanaan desentralisasi. Salah satu dana perimbangan dari pemerintah ini adalah Dana Alokasi Umum (DAU) yang pengalokasiannya menekankan aspek pemerataan dan keteradilan yang selaras dengan penyelengaraan urusan pemerintahan (Undang-Undang Nomor 32 Tahun 2004). Dengan adanya transfer dari pusat ini diharapkan pemerintah daerah mampu mengalokasikan PAD yang didapatnya untuk membiayai Belanja Modal di daerahnya. Namun pada kenyataannya, transfer dari pemerintah pusat merupakan sumber dana utama pemerintah daerah untuk membiayai operasi utamanya sehari-hari atau belanja daerah. Belanja Modal merupakan bagian dari belanja daerah yang juga didanai dari DAU, dan diperhitungkan oleh pemerintah daerah dalam APBD.

Dana transfer dari pemerintah pusat ke pemerintah daerah selain DAU adalah Dana Alokasi Khusus (DAK) yaitu dana yang bersumber dari pendapatan APBN yang dialokasikan kepada daerah tertentu dengan tujuan untuk membantu mendanai kegiatan khusus yang merupakan urusan 
daerah dan sesuai dengan prioritas nasional (Undang-Undang Nomor 33 Tahun 2004). DAK ini penggunaannya diatur oleh pemerintah pusat, dan hanya digunakan untuk kegiatan pendidikan, kesehatan, keluarga berencana, insfrastruktur jalan dan jembatan, insfrastruktur irigasi, insfrastruktur air minum dan sanitasi, prasaran pemerintah daerah, lingkungan hidup, kehutanan, sarana prasaran pedesaan, perdagangan, pertanian serta perikanan dan kelautan yang semuanya itu termasuk dalam Belanja Modal dan pemerintah daerah diwajibkan untuk mengalokasikan dana pendamping sebesar $10 \%$ dari nilai DAK yang diterimanya untuk kegiatan fisik, oleh sebab itu dalam penelitian DAK tidak digunakan sebagai variabel independen yang mempengaruhi Belanja Modal.

- Berdasarkan permasalahan dari berbagai paragraf sebelumnya. Peneliti ingin mengetahui apakah Pendapatan Asli Daerah (PAD), dan Dana Alokasi Umum (DAU) berpengaruh terhadap Belanja Modal di kabupaten/kota yang berada di Pulau Jawa pada periode tahun 2013. Berkaitan dengan permasalahan ini, maka judul skripsi ini yaitu "Pengaruh Pendapatan Asli Daerah dan Dana Alokasi Umum terhadap Belanja Modal pada Kabupaten dan Kota di Pulau Jawa Tahun 2013 “.

\section{METODE PENELITIAN}

Jenis Penelitian

Penelitian ini merupakan jenis penelitian kausal komparatif dengan pendekatan kuantitatif.

\section{Waktu dan Tempat Penelitian}

Waktu dari penelitian ini dilaksanakan pada tahun 2016 dengan mengunjungi situs resmi Direktorat Jenderal Perimbangan Keuangan Daerah Kemenkeu RI yaitu www.depkeu.djpk.go.id.

\section{Populasi Penelitian}

Populasi dalam penelitian ini adalah Seluruh Kabupaten dan Kota di Pulau Jawa dengan pengecualian pada Kabupaten dan Kota yang berada di Provinsi DKI Jakarta dan Pulau Madura. Populasi dalam penelitian ini berjumlah 108 kabupaten/kota dalam penelitian ini.

\section{Prosedur}

Teknik pengumpulan data dalam penelitian ini dilakukan dengan metode dokumentasi yaitu dengan melakukan pengumpulan dokumen terlebih dahulu, kemudian dokumen tersebut dipelajari dan dilanjutkan dengan proses pencatatan dan penghitungan terhadap data-data yang bersifat relevan pada permasalahan di penelitian ini. 
Data, Instrumen, dan Teknik Analisis data

\section{Data dan Instrumen}

Data penelitian ini adalah data sekunder. Pemerolehan data dilakukan dengan mengunjungi situs resmi Direktorat Jenderal Perimbangan Keuangan Daerah Kemenkeu RI yaitu www.depkeu.djpk.go.id. Masing-masing variabel diperoleh berdasarkan instrumen penelitian sebelumnya yang didasari oleh sumbernya dari dokumen Laporan Realisasi Anggaran (LRA) yang dipublikasikan oleh Direktorat Jenderal Perimbangan Keuangan Daerah.

Teknik Analisis Data

Kuesioner yang nantinya akan disebarkan kepada responden harus diuji terlebh dahulu validitas dan reliabilitasnya.

Uji coba instrumen dilakukan kepada 30 responden di luar populasi. Uji coba instrumen akan dilakukan di Dinas Sosial, Tenaga Kerja dan Transmigrasi Kota Yogyakarta. Setelah diperoleh data penelitian, dilakukan uji prasyarat analisis yang meliputi uji normalitas dan uji linieritas dan uji asumsi klasik yang meliputi uji multikolinearitas dan uji heteroskedastisitas. Metode analisis data yang digunakan adalah analisis regresi linier sederhana dan analisis regresi linier moderasi.

Pengambilan data secara sekunder, dilakukan dengan metode dokumentasi dari Laporan Realisasi Anggaran (LRA) tahun 2013 dari situs Dirjen Perimbangan Keuangan Daerah Kemenkeu RI melalui www.depkeu.djpk.go.id. Setelah diperoleh data penelitian, dilakukan uji asumsi klasik dan uji hipotesis. Uji asumsi klasik dengan menggunakan uji normalitas, uji multikolonieritas, dan uji heteroskedastisitas. Uji hipotesis dilakukan dengan menggunakan uji regresi linier sederhana dan uji regresi linier berganda.

HASIL PENELITIAN DAN PEMBAHASAN

Objek dari penelitian ini adalah Kabupaten dan Kota di Pulau Jawa. Jumlah Kabupaten dan Kota di Pulau Jawa berjumlah 118 Kabupaten dan Kota. Pulau Jawa merupakan pulau dengan letak geografis yang berbatasan dengan Pulau Kalimantan di sebelah utara, Pulau Sumatra di sebelah barat, Pulau Bali di sebelah timur, dan Samudra Hindia di sebelah selatan. Data pada penelitian ini (N) sebanyak 108, yang diperoleh dari Laporan Realisasi APBD Kabupaten dan Kota di Pulau Jawa tahun 2013 dan kecuali pada Kabupaten dan Kota di Provinsi DKI Jakarta dan Pulau Madura yang tidak termasuk dalam penelitian ini. Kemudian, Kabupaten dan Kota tersebut 
yang menyampaikan laporan kepada situs Dirjen Perimbangan Keuangan Pemerintah Daerah tahun 2013.

Dari hasil pengumpulan data sekunder mengenai Pendapatan Asli Daerah, Dana Alokasi Umum, dan Belanja Modal pada Kabupaten dan Kota di Pulau Jawa Tahun 2013, dapat dipaparkan sebagai berikut:

\section{Belanja Modal}

Melalui hasil dari tahap pemerosesan pengolahan data dengan bantuan program IBM SPSS Statistics Version 20. Jumlah populasi yang diteliti yaitu sejumlah 108 . Variabel Belanja Modal mempunyai nilai minimalnya sebesar Rp 67.646.320.365 yang diperoleh dari Kota Mojokerto, dan nilai maksimalnya sebesar Rp 1.316.781.706.310 yang diperoleh dari Kabupaten Bogor. Nilai mean 304193715698,80 dan nilai standar deviasi $246311956916,034$.

\section{Pendapatan Asli Daerah}

Melalui hasil dari tahap pemerosesan pengolahan data dengan bantuan program IBM SPSS Statistics Version 20. Jumlah populasi yang diteliti yaitu sejumlah 108 . Variabel Pendapatan Asli Daerah mempunyai nilai minimalnya sebesar $\mathrm{Rp}$ 59.544.940.728 diperoleh dari Kota Batu, dan nilai maksimalnya sebesar $\mathrm{Rp}$ 2.791.580.050.710 diperoleh dari Kota Surabaya. Nilai mean 277254724762,86, dan nilai standar deviasi 364824015856,134 .

\section{Dana Alokasi Umum}

Melalui hasil dari tahap pemerosesan pengolahan data dengan bantuan program IBM SPSS Statistics Version 20. Jumlah populasi yang diteliti yaitu sejumlah 108, variabel Dana Alokasi Umum mempunyai nilai minimalnya sebesar $\mathrm{Rp}$ 317.122.023.000 yang diperoleh dari Kota Banjar, dan nilai maksimalnya sebesar $\mathrm{Rp}$ 1.887.770.112.500 yang diperoleh dari Kabupaten Bogor. Nilai mean 858960737597,22 , dan nilai standar deviasi $299627176459,941$.

\section{Analisis Data}

Tabel 1. Uji Normalitas dari hasil uji One-Sample KolmogorovSmirnov Test

\begin{tabular}{|c|c|c|}
\hline & & $\begin{array}{c}\text { Unstandardized } \\
\text { Residual } \\
\end{array}$ \\
\hline$N$ & & 108 \\
\hline \multirow{3}{*}{$\begin{array}{l}\text { Normal } \\
\text { Parameters }{ }^{a, b}\end{array}$} & Mean & $-0,0000559$ \\
\hline & Std. & 100834298418.48900 \\
\hline & Deviation & 000 \\
\hline \multirow{2}{*}{ Most Extreme } & Absolute & 0,123 \\
\hline & Positive & 0,123 \\
\hline Differences & Negative & $-0,075$ \\
\hline \multicolumn{2}{|c|}{ Kolmogorov-Smirnov $Z$} & 1,279 \\
\hline \multicolumn{2}{|c|}{ Asymp. Sig. (2-tailed) } & 0,076 \\
\hline
\end{tabular}

a. Test distribution is Normal.

b. Calculated from data.

Sumber: Output SPSS 20, data sekunder yang diolah

Hasil uji normalitas ini dapat dilihat pada tabel 1 Nilai Kolmogorov-Smirnov 1,279 dengan probabilitas signifikansi 0,076 lebih dari $\alpha=0,05$, berarti data 
terdistribusi secara normal, dan model regresi ini memenuhi uji normalitas.

Tabel 2. Matriks Korelasi untuk Uji Multikolinearitas

\begin{tabular}{cccc}
\hline Model & & \multicolumn{1}{c}{ DAU } & PAD \\
\hline \multirow{3}{*}{ Correlations } & DAU & 1,000 & $-0,389$ \\
& PAD & $-0,389$ & 1,000 \\
Covariances & DAU & 0,001 & 0,000 \\
& PAD & 0,000 & 0,001
\end{tabular}

a. Dependent Variable: Belanja Modal

Sumber: Output SPSS 20, data sekunder yang diolah

Berdasarkan tabel 2 tersebut menunjukkan bahwa hasil besaran korelasi antar variabel independen tampak bahwa hanya variabel Pendapatan Asli Daerah (PAD) yang mempunyai korelasi cukup tinggi dengan variabel Dana Alokasi Umum (DAU) dengan tingkat korelasi sebesar -0,389. Karena korelasi ini masih di bawah 0,60 atau 60\%, maka dapat dikatakan tidak terjadi multikolonieritas yang serius.

\section{Gambar 1. Diagram Heteroskedastisitas}

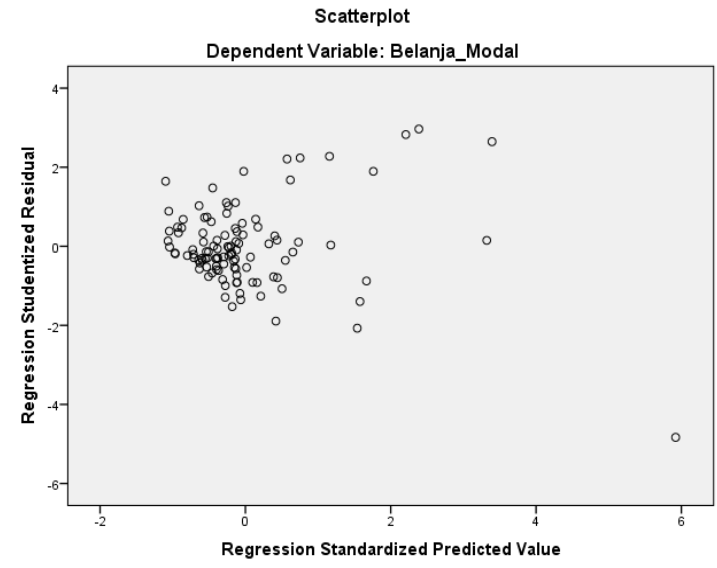

Sumber: Output SPSS 20, data sekunder yang diolah
Dari gambar 1 di atas terlihat titiktitik menyebar secara acak serta tersebar baik di atas maupun di bawah angka 0 pada sumbu $\mathrm{Y}$, tidak ada pola tertentu yang teratur. Dengan demikian, dapat disimpulkan bahwa tidak terjadi heteroskedastisitas pada model regresi ini.

\section{Hasil Uji Hipotesis}

$\mathrm{H}_{1}$ : Pendapatan Asli Daerah berpengaruh positif terhadap Belanja Modal pada Kabupaten dan Kota di Pulau Jawa Tahun 2013.

Tabel 3. Rangkuman Hasil Uji Hipotesis 1

\begin{tabular}{lcc}
\hline Variabel & $\begin{array}{c}\text { Koefisien regresi } \\
\text { Konstanta }\end{array}$ & thitung \\
\hline Pendapatan & $0,582.755 .832,1$ & \\
Asli Daerah & & 17,5 \\
$\mathrm{R} \quad: 0,862$ & & 39 \\
$R^{2} \quad: 0,744$ & & \\
\hline
\end{tabular}

Sumber: Output SPSS 20, data sekunder yang diolah

Berdasarkan tabel di atas dapat dilihat bahwa nilai konstanta sebesar 142.762.755.832,1. Nilai koefisien Pendapatan Asli Daerah (PAD) sebesar 0,582. Dengan demikian, maka arah model regresi tersebut adalah positif. Hal ini juga dapat dilihat dari nilai korelasi regresi (R) yang bernilai positif antara Pendapatan Asli Daerah dan Belanja Modal yaitu sebesar 0,862. Oleh karena itu, semakin tinggi Pendapatan Asli Daerah maka akan semakin tinggi pula Belanja Modal. Nilai koefisien determinasi $\mathrm{R}^{2}$ sebesar 0,744 . 
Hal tersebut menunjukkan bahwa sebesar 74,4\% Belanja Modal dipengaruhi oleh Pendapatan Asli Daerah, sedangkan sisanya sebesar $25,6 \%$ dipengaruhi oleh variabel lain di luar penelitian ini.

Pada hasil pengujian analisis regresi linear sederhana antara Pendapatan Asli Daerah dengan Belanja Modal diperoleh $t$ hitung lebih besar daripada $\mathrm{t}$ tabel yaitu $\mathrm{t}$ hitung sebesar 17,539 dan t tabel sebesar 1,98282. Berdasarkan hasil yang diperoleh pada pengujian regresi linear sederhana ini, maka dapat disimpulkan bahwa Pendapatan Asli Daerah berpengaruh signifikan terhadap Belanja Modal pada Kabupaten dan Kota di Pulau Jawa Tahun 2013. Dengan demikian, maka hipotesis pertama diterima.

Hasil penelitian ini mendukung hasil penelitian Saptaningsih Sumarmi (2009) dengan judul "Pengaruh Pendapatan Asli Daerah, Dana Alokasi Umum, Dan Dana Alokasi Khusus Terhadap Belanja Modal Daerah Kabupaten/Kota Di Provinsi D.I. Yogyakarta". Hasil penelitian tersebut menyatakan bahwa Pendapatan Asli Daerah berpengaruh positif dan signifikan terhadap Belanja Modal.

$\mathrm{H}_{2}$ : Dana Alokasi Umum berpengaruh positif terhadap Belanja Modal pada Kabupaten dan Kota di Pulau Jawa Tahun 2013.
Tabel 4. Rangkuman Hasil Uji Hipotesis 2

\begin{tabular}{lcc}
\hline \multicolumn{1}{c}{ Variabel } & Koefisien regresi & $\mathbf{t}_{\text {hitung }}$ \\
\hline Konstanta & -126.328 .342 .848 & \\
\hline $\begin{array}{l}\text { Pendapata } \\
\text { n Asli }\end{array}$ & 0,501 & 7,920 \\
Daerah & & \\
\hline $\mathbf{R} \quad \mathbf{0 , 6 1 0}$ & & \\
\hline $\boldsymbol{R}^{\mathbf{2}} \mathbf{: 0 , 3 7 2}$ & & \\
\hline
\end{tabular}

Sumber: Output SPSS 20, data sekunder yang diolah

Berdasarkan tabel di atas dapat dilihat bahwa nilai konstanta sebesar 126.328.342.848. Nilai koefisien Pendapatan Asli Daerah (PAD) sebesar 0,501. Dengan demikian, maka arah model regresi tersebut adalah positif. Hal ini juga dapat dilihat dari nilai korelasi regresi $(\mathrm{R})$ yang bernilai positif antara Dana Alokasi Umum dan Belanja Modal yaitu sebesar 0,610. Oleh karena itu, semakin tinggi Pendapatan Asli Daerah maka akan semakin tinggi pula Belanja Modal. Nilai koefisien determinasi $\mathrm{R}^{2}$ sebesar 0,372. Hal tersebut menunjukkan bahwa sebesar 37,2\% Belanja Modal dipengaruhi oleh Dana Alokasi Umum, sedangkan sisanya sebesar $62,8 \%$ dipengaruhi oleh variabel lain di luar penelitian ini.

Pada hasil pengujian analisis regresi linear sederhana antara Dana Alokasi Umum dengan Belanja Modal diperoleh $\mathrm{t}$ hitung lebih besar daripada $t$ tabel yaitu $t$ hitung sebesar 7,920 dan $t$ tabel sebesar 1,98282. Berdasarkan hasil yang diperoleh pada pengujian regresi linear sederhana 
ini, maka dapat disimpulkan bahwa Dana Alokasi Umum berpengaruh signifikan terhadap Belanja Modal pada Kabupaten dan Kota di Pulau Jawa Tahun 2013. Dengan demikian, maka hipotesis kedua diterima.

Hasil penelitian ini mendukung hasil penelitian Kefas Caesar Pradata (2015) dengan judul "Pengaruh Pendapatan Asli Daerah (PAD) Dan Dana Alokasi Umum (DAU) Terhadap Belanja Modal Di Jawa Tengah Tahun 2011-2013”. Hasil penelitian tersebut menyatakan bahwa Dana Alokasi Umum berpengaruh positif dan signifikan terhadap Belanja Modal.

$\mathrm{H}_{3}$ : Pendapatan Asli Daerah (PAD) dan Dana Alokasi Umum (DAU) berpengaruh positif secara bersama-sama pada Kabupaten dan Kota di Pulau Jawa Tahun 2013.

Tabel 5. Rangkuman Hasil Uji Hipotesis 3

\begin{tabular}{ll}
\hline \multicolumn{1}{c}{ Variabel } & \multicolumn{1}{c}{ Koefisien regresi } \\
\hline Konstanta & -61.956 .430 .528 \\
\hline Pendapatan & 0,497 \\
Asli Daerah & \\
\hline Dana Alokasi & 0,266 \\
Umum & \\
\hline $\mathbf{R} \quad \mathbf{0 , 9 1 2}$ & \\
\hline $\mathbf{R}^{2} \quad \mathbf{0 , 8 3 2}$ & \\
\hline
\end{tabular}

\section{F hitung : 260,766}

Sumber: Output SPSS 20, data sekunder yang diolah
Berdasarkan tabel di atas, diketahui bahwa nilai konstanta sebesar 61.956.430.528. Pendapatan Asli Daerah mempunyai nilai koefisien 0,497. Dana Alokasi Umum mempunyai nilai koefisien 0,266. Hasil tersebut menunjukkan bahwa Pendapatan Asli Daerah dan Dana Alokasi Umum secara bersama-sama berpengaruh positif terhadap Belanja Modal Pada Kabupaten dan Kota di Pulau Jawa Tahun 2013. Nilai $R^{2}$ sebesar 0,832 menunjukkan bahwa sebesar 83,2\% Belanja Modal pada Kabupaten dan Kota di Pulau Jawa Tahun 2013 dipengaruhi oleh Pendapatan Asli Daerah dan Dana Alokasi Umum sedangkan sisanya sebesar $16,8 \%$ dipengaruhi oleh variabel lain di luar penelitian ini.

Pengujian hipotesis 3 menunjukkan bahwa hasil pengujian statistik dengan uji F diterangkan melalui $F_{\text {tabel }}$ sebesar 3,08 dan $F_{\text {hitung }}$ sebesar 260,766, maka $F_{\text {hitung }}>$ $F_{\text {tabel }}$ dengan berarti secara bersama-sama Pendapatan Asli Daerah dan Dana Alokasi Umum berpengaruh signifikan terhadap Belanja Modal pada Kabupaten dan Kota di Pulau Jawa Tahun 2013. Dengan demikian, maka hipotesis ketiga diterima.

Hasil penelitian ini mendukung hasil dari penelitian Kefas Caesar Pradata (2015) dengan judul "Pengaruh Pendapatan Asli Daerah (PAD) Dan Dana Alokasi Umum (DAU) Terhadap Belanja Modal Di Jawa Tengah Tahun 2011- 


\section{JURNAL NOMINAL / VOLUME VI NOMOR 1 / TAHUN 2017}

2013”. Hasil penelitian tersebut menyatakan bahwa Pendapatan Asli Daerah (PAD) dan Dana Alokasi Umum (DAU) berpengaruh positif dan signifikan secara simultan terhadap Belanja Modal.

\section{SIMPULAN DAN SARAN}

\section{Simpulan}

a. Pengujian yang dilakukan memberikan hasil yang mendukung dan menerima hipotesis 1 yaitu Pendapatan Asli Daerah berpengaruh positif dan signifikan terhadap Belanja Modal pada Kabupaten dan Kota di Pulau Jawa. Hal ini ditunjukkan dengan nilai koefisien korelasi $\left(\mathrm{r}_{1 \mathrm{y}}\right)$ sebesar 0,862 dan koefisien determinasi $\left(\mathrm{r}^{2}{ }_{1 \mathrm{y}}\right)$ sebesar 0,744. Nilai $\mathrm{t}$ hitung lebih besar daripada $\mathrm{t}$ tabel yaitu $\mathrm{t}$ hitung sebesar 17,539 dan t tabel sebesar 1,98282.

b. Pengujian yang dilakukan memberikan hasil yang mendukung dan menerima hipotesis 2 yaitu Dana Alokasi Umum berpengaruh positif dan signifikan terhadap Belanja Modal pada Kabupaten dan Kota di Pulau Jawa. Hal ini ditunjukkan dengan nilai koefisien korelasi $\left(\mathrm{r}_{2 \mathrm{y}}\right)$ sebesar 0,610 dan koefisien determinasi $\left(\mathrm{r}^{2}{ }_{1 \mathrm{y}}\right)$ sebesar 0,372 . Nilai $t$ hitung lebih besar daripada $\mathrm{t}$ tabel yaitu $\mathrm{t}$ hitung sebesar 7,920 dan t tabel sebesar 1,98282.

c. Pengujian yang dilakukan memberikan hasil yang menolak hipotesis 3 yang menyatakan bahwa Pendapatan Asli
Daerah dan Dana Alokasi Umum secara bersama-sama berpengaruh positif dan signifikan terhadap Belanja Modal pada Kabupaten dan Kota di Pulau Jawa. Hal ini ditunjukkan dengan nilai koefisien korelasi $\left(\mathrm{R}_{1,2 \mathrm{y}}\right)$ sebesar 0,912 dan koefisien determinasi $\left(\mathrm{R}_{1,2 \mathrm{y}}^{2}\right)$ sebesar 0,832. Nilai $F$ hitung lebih besar daripada $\mathrm{F}$ tabel yaitu $\mathrm{F}$ hitung sebesar 260,766 dan F tabel sebesar 3,08.

\section{Saran}

a. Bagi Pemerintah Daerah

1. Bagi penyelenggara pelayanan publik khususnya pemerintah daerah diharapkan bisa terus menggali sumbersumber Pendapatan Asli Daerah agar berguna dalam pendanaan untuk meningkatkan mutu dari pelayanan publik di daerah.

2. Pemerintah daerah diharapkan mampu dengan baik mengelola dan memanfaatkan sepenuhnya Dana Alokasi Umum untuk meningkatkan mutu dari pelayanan publik di daerah.

3. Pemerintah daerah diharapkan mampu memprioritaskan dana yang dimiliki daerah ke dalam Belanja Modal agar berguna bagi kepentingan umum daerah dalam meningkatkan infrastruktur dan sarana pada daerah yang dapat menunjang kehidupan masyarakat di daerah.

b. Bagi Penelitian Selanjutnya 
Pada penelitian selanjutnya diharapakan dapat menambah cakupan daerah kabupaten atau kota khususnya yang berada di luar Pulau Jawa, supaya hasil dari penelitian yang dilakukan lebih representatif.

\section{DAFTAR PUSTAKA}

Abdul Halim. (2007). Akuntansi Sektor Publik : Akuntansi Keuangan Daerah. Edisi 3. Jakarta : Penerbit Salemba Empat.

Allen, Richard \& Tommasi, Danniel. (2001). Managing Public Expenditure : A Reference Book for Transition Countries. Paris: OECD.

Bambang Kesit Prakosa. (2004). "Analisis Pengaruh Dana Alokasi Umum (DAU) dan Pendapatan Asli Daerah (PAD) Terhadap Prediksi Belanja Daerah (Studi Empirik Di Wilayah Provinsi Jawa Tengah dan DIY)." Jurnal Akuntansi \&Auditing Indonesia, Volume 8 No 2, 101-118.

Danang Sunyoto. (2007). Analisis Regresi dan Korelasi Bivariat : Ringkasan dan Kasus. Yogyakarta : Amara Books.

Dini Arwati dan Novita Hadiati. (2013). "Pengaruh Pertumbuhan Ekonomi, Pendapatan Asli Daerah dan Dana Alokasi Umum Terhadap Pengalokasian Anggaran Belanja Modal pada Pemerintah Daerah Kabupaten/Kota di Propinsi Jawa Barat". Seminar Nasional Teknologi Informasi \& Komunikasi Terapan 2013 (Semantik 2013).

Kefas Caesar Pradata. (2015). “ Pengaruh Pendapatan Asli Daerah (PAD) Dan Dana Alokasi Umum (DAU) Terhadap Belanja Modal Di Jawa Tengah Tahun 2011-2013”. Skripsi. Universitas Negeri Yogyakarta.
Kemenkeu DJPK.

http://www.djpk.depkeu.go.id/?page id $=316$. Pada tanggal 10 Februari 2016

Selayang "Pandang".
http://www.kemenkeu.go.id/sites/def ault/files/DAU.pdf. Pada tanggal 13 Mei 2016

Imam Ghozali. (2011). Aplikasi Analisis Multivariate dengan Program IBM SPSS 19. Edisi 5. Semarang : Badan Penerbit Universitas Diponegoro.

Lembaran Negara Republik Indonesia. Undang-undang Nomor 22 Tahun 1999 Tentang Dana Perimbangan.

Lembaran Negara Republik Indonesia. Peraturan Pemerintah No.104 Tahun 2000 Tentang Dana Perimbangan.

Lembaran Negara Republik Indonesia. Undang-Undang Nomor 34 Tahun 2000 Tentang Pajak Daerah dan Retribusi Daerah.

Lembaran Negara Republik Indonesia. Peraturan Pemerintah Nomor 65 Tahun 2001 Tentang Pajak Daerah.

Lembaran Negara Republik Indonesia. Undamg-Undang Nomor 32 Tahun 2004 Tentang Pemerintah Daerah.

Lembaran Negara Republik Indonesia. Undang-Undang Nomor 33 Tahun 2004 Tentang Perimbangan Keuangan Antara Pemerintah Pusat dan Pemerintah Daerah.

Lembaran Negara Republik Indonesia. Peraturan Pemerintah Nomor 55 Tahun 2005 Tentang Dana Perimbangan.

Lembaran Negara Republik Indonesia. Peraturan Pemerintah No.24 Tahun 
2005 Tentang Standar Akuntansi Pemerintahan.

Lembaran Negara Republik Indonesia. Peraturan Pemerintah No.58 Tahun 2005 Tentang Pengelolaan Keuangan Daerah.

Lembaran Negara Republik Indonesia. Peraturan Pemerintah No.13 Tahun 2006 Tentang Pedoman Pengelolaan Keuangan Daerah.

Lembaran Negara Republik Indonesia. Peraturan Menteri Keuangan Nomor 91/PMK. 05/ 2007 Tentang Bagan Akun Standar. Lampiran Peraturan Menteri Keuangan Nomor 91/PMK. 05/ 2007 Tentang Bagan Akun Standar.

Lembaran Negara Republik Indonesia. Undamg-Undang Nomor 28 Tahun 2009 Tentang Pajak Daerah dan Retribusi Daerah.

Lembaran Negara Republik Indonesia. Undamg-Undang Nomor 23 Tahun 2014 Tentang Pemerintah Daerah.

Mardiasmo. (2002). Otonomi dan Manajemen Keuangan Daerah. Yogyakarta: Penerbit Andi Yogyakarta.

\section{(2002). Akuntansi Sektor} Publik. Yogyakarta: Penerbit Andi.

Saptaningsih Sumarmi. (2009)."Pengaruh Pendapatan Asli Daerah, Dana Alokasi Umum, Dan Dana Alokasi Khusus Terhadap Belanja Modal Daerah Kabupaten/Kota Di Provinsi D.I. Yogyakarta".

Saragih, Juli Panglima. (2003). Desentralisasi Fiskal dan Keuangan Daerah dalam Otonomi. Jakarta: Penerbit Ghalia Indonesia.
Sugiyono. (2007). Statistika Untuk Penelitian. Bandung: penerbit Alfabeta. . (2011). Metode Penelitian Kuantitatif Kualitatif dan $R \& D$. Bandung :Penerbit Alfabeta

Syaiful. (2006). "Pengertian dan Perlakuan Akuntansi Belanja Barang dan Belanja Modal dalam Kaidah Akuntansi Pemerintahan". Diambil dari http://www.ksap.org/Riset\&Artikel/ Art16.pdf. Pada tanggal 9 Februari 2016.

Syukriy Abdullah dan Abdul Halim. (2003). "Pengaruh Dana Alokasi Umum (DAU) dan Pendapatan Asli Daerah Terhadap Belanja Pemerintah Daerah: Studi Kasus Kabupaten/Kota di Jawa dan Bali”. Simposium Nasional Akuntansi VI. Surabaya 